Мазаракі А.А., д. е. н., проф., ректор Київський національний торговельно-економічний університет, м. Київ, Україна

Scholar https://scholar.google.com.ua/citations?user=3woxqoQAAAAJ\&hl=ru\&oi $=\mathrm{ao}$ Scopus https://www.scopus.com/authid/detail.uri?authorId=56786319100 ORCID http://orcid.org/0000-0001-5283-8444

\title{
ДЕТЕРМІНАНТИ РОЗВИТКУ ТУРИЗМУ
}

Світова інтеграція характеризується високим динамізмом процесів, які впливають на всі сфери економіки, а тому без превентивного реагування на зовнішні дисбаланси успішний соціально-економічний розвиток буде ускладнений. Особливо це актуально для туристичної системи, що має глобальний характер i взаємопов'язана 3 економічними циклами розвитку суспільства. Спад або підйом економіки країни істотно впливає на динаміку туристичних потоків. Нині світова туристична система формує 9,5\% ВВП і забезпечує 266 млн робочих місць у економіці. На основі поточної тенденції і прогнозу на майбутнє аналітики UNWTO припускають, що кількість міжнародних туристичних візитів у світі продовжить зростати [1].

Україна демонструє політику відкритості й інтеграції до світового господарства. Відтак прогнози щодо розвитку національної туристичної системи позитивні, проте рівень невизначеності i волатильності високий. За даними Державної служби статистики України, в 2018 р. нашу країну відвідало 13333,0 тис. іноземних осіб і осіб без громадянства, що на 7,3\% більше, ніж у 2017 р., коли цей показник становив 12428,3 тис. осіб [2]. Це досить позитивні тенденції. Ці фактори призвели також і до змін структури в'їзного туристичного потоку.

За умови нестабільності зовнішнього середовища, коливання кон'юнктури, загострення конкуренції на ринку туристичних послуг зростає потреба у визначенні детермінантів розвитку туризму. Проаналізувавши результати досліджень щодо виявлення головних драйверів розвитку туризму, експерти визначили, що в умовах переходу економічних систем до постіндустріальної (інформаційної) 
ери, зростає необхідність орієнтування на характерні ій «проривні інновації», якими є продукти і сервіси, що відповідають запитам інформаційної економіки - технологічні стартапи.

Поширення технологічних мегатрендів - результат глобалізації. Вони можуть спричинити кардинальні зміни у світовій туристичній системі і, відповідно, туристичній системі України. При цьому, вплив технологічних трендів на туризм - це технології блокчейн та іiі потенційні можливості, пов'язані 3 процедурами ідентифікації туристів, покращення якості обслуговування, появою кардинально інших механізмів організації подорожей, можливостями моніторингу ринку туристичних послуг тощо. Україна, маючи досить потужну ITіндустрію, повинна вже зараз закладати інноваційні основи туристичної діяльності. Нині НБУ вивчає можливість запровадження е-гривні (електронної національної валюти), в основу якої покладено технологію блокчейн. Окрім того, Україна першою у світі запустила електронний державний аукціон на основі технології блокчейн систему державних електронних торгів із заставним майном (СЕТАМ), після ребрендингу - торгова марка OpenMarket [3]. Формування моделі національної цифрової економіки може здійснити функції акселератора розвитку як загалом країни, так і ії національної туристичної системи.

Детермінантами розвитку туризму $є$ :

- посилення впливу централізованих (Booking, Airbnb) та децентралізованих платформ (так звані «убивці Airbnb», що звільняють готелі та споживачів від сплати комісійних зборів) бронювання засобів розміщення; соціальних мереж, хостингів, мобільних технологій (Facebook, Instagram, Youtube, Viber, TripAdwisor);

- поширення мобільних додатків;

- зростання придбань туристичних продуктів і послуг в Інтернет-середовищі;

- зростання залежності, бронювань послуг від кількості відвідувань сайту (конверсія);

- упровадження технологій спільного споживання.

Важливим маркером розвитку туризму є обсяги обслуговуваних іноземних громадян, для яких визначено такі тенденції:

- значне розширення ринку авіаперевезень (прихід та/або повернення на український ринок авіакомпаній (Wizz Air, Emirates, Vueling Airlines, Qatar Airways, El Al, Flydubai, Air Arabia, Alitalia, тощо); формування національного low cost - перевізника Sky Up); 
- зростання автомобільних перевезень у міжнародному сполученні;

- запровадження біометричних технологій та електронних віз і активізація діяльності державних органів влади щодо спрощення / відміни візових режимів з окремими країнами та навпаки - посилення біометричного контролю на кордонах країни щодо громадян окремих держав;

- запровадження інноваційних технологій (спеціалізовані сайти та портали (TripMyDream, ZruchnoTravel), мобільний додаток «Турист України», туристичний хакатон);

- започаткування діяльності щодо створення регіональних туристичних продуктів «Україна - Туреччина», «Україна - Грузія»;

- активізація промоції туристичних можливостей України за кордоном та для зарубіжних партнерів.

Необхідність фокусування на ключових напрямах мейнстриму глобальних тенденцій особливо важлива для активізації виходу вітчизняного туристичного бізнесу на зовнішній ринок туристичної пропозиції, тому що посилить позицію національного туризму, його імідж та стратегічну стійкість на міжнародному ринку.

\section{Список бібліографічних посилань}

1. Travel \& Tourism Economic Impact 2017 World [Електронний pecypc]. - Режим доступу : http://www.wttc.org

2. Туристичні потоки : Державна служба статистики України. Електронний ресурс. Режим доступу : http://www.ukrstat.gov.ua/

3. CETAM. OpenMarket. Офіційний сайт. Електронний pecypc. Режим доступу : https://setam.net.ua/ 